Int. J. Mol. Sci. 2002, 3, 1177-1187

International Journal of

Molecular Sciences

ISSN 1422-0067

(C) 2002 by MDPI

www.mdpi.org/ijms/

\title{
Expression of Chemokines, MIP-1alpha and RANTES in Caprine Lentiviral Infection and Their Influence on Viral Replication
}

\author{
S. Punna ${ }^{1 *}$, A. K. Jones ${ }^{1}$, and P.G. Reddy ${ }^{1,2}$ \\ ${ }^{1}$ Center for Biomedical Research/RCMI, Carver Research Foundation; ${ }^{2}$ Dept. of Pathobiology, School \\ of Veterinary Medicine, Nursing \& Allied Health, Tuskegee University, Tuskegee, AL 36088 USA \\ *Author to whom correspondence should be addressed: Tel: 334-727-8270; Fax: 334-727-2069; \\ E-mail:punna28@hotmail.com
}

Received: 7 June 2002 / Accepted: 30 October 2002 / Published: 30 November 2002

\begin{abstract}
Chemokines belong to a super family of inducible and secreted, pro-inflammatory cytokines. They act primarily as chemoattractants and activators of specific types of leukocytes and are involved in a variety of immune and inflammatory responses. The status and role of chemokines, macrophage inflammatory protein (MIP-1 $\alpha$ ) and RANTES (Regulated upon Activation Normal T-cell Expressed and Secreted) in the immunopathogenesis by caprine arthritis-encephalitis virus (CAEV) are not fully elucidated. The objectives of this study were to, 1) determine the expression MIP- $1 \alpha$ in goat synovial membrane cells (GSM cells) infected in vitro, and peripheral blood mononuclear cells (PBMC) of CAEV infected goats by RT-PCR, and 2) effect of exogenous MIP-1 $\alpha$ and on replication of CAEV in GSM cells in vitro. RT-PCR results indicated higher expression of MIP-1 $\alpha$ in PBMC of CAEV-infected goats as compared to controls. Similarly, higher expression of MIP-1 $\alpha$ was observed in GSMC infected in vitro with CAEV as compared to that in uninfected cells. Exogenous MIP-1 $\alpha(20 \mathrm{ng} / \mathrm{ml})$ and RANTES $(20 \mathrm{ng} / \mathrm{ml})$ significantly inhibited CAEV replication in GSM cells by $75 \%$ and $65 \%$, respectively as compared to the replication in GSM cells not treated with the chemokines. Results of this study suggest that CAEV infection may alter the expression of chemokines in goats, which may suppress the replication of the virus.
\end{abstract}

Keywords: CAEV-infection, chemokines, lentivirus, MIP-1 $\alpha$, RANTES. 


\section{Introduction}

Caprine arthritis encephalitis virus (CAEV) is a non-oncogenic retrovirus belonging to the subfamily lentivirinae. Exposure of goats to CAEV results in chronic mononuclear infiltration of various tissues [1]. It leads to persistent infection and chronic arthritis in goats, which shows remarkable histopathological similarity to rheumatiod arthritis (RA) in humans. Feldman et al. [2] reported that the potential role of various cytokines and disruption in their normal function could lead to exacerbation of the inflammatory process in RA.

Chemokines are small inducible, and secreted (SIS) cytokines that are involved in a variety of immune and inflammatory processes mainly due to their chemotactic activity for specific types of leukocytes [3]. RANTES and MIP-1 $\alpha$, two important pro-inflammatory chemokines belong to CCchemokine subfamily [4]. RANTES is produced by circulating T-cells. Its synthesis is induced by TNF- $\alpha$ and IL-1 $\alpha$ and inhibited by the stimulation of T-lymphocytes. RANTES is chemotactic for Tcells, eosinophils, and basophils [5]. RANTES was also reported to be highly expressed in human synovial fibroblast of patients suffering from RA suggesting its role in the inflammatory process [6]. MIP-1 $\alpha$, produced by bacterial endotoxin stimulated macrophages, plays an important role in inflammation by inducing synthesis of other proinflammatory cytokines such as IL-1 $\beta$, IL-6. It activates neutrophils, eosinophils and basophilic granulocytes and is involved in acute neutrophilic inflammation. MIP-1 $\alpha$ is also known to induce the proliferation and activation of killer cells known as CHAK killer cells [4].

It has been shown that the altered expression and response of various chemokines may play a critical role in the immuno- and histopathology of infected goat [7]. Since MIP-1 $\alpha$ and RANTES are important pro-inflammatory cytokines, any alteration in their normal expression and function could subsequently affect immunopathology in the goat including the development of arthritis and replication of CAEV in infected goats. It has been shown that some chemokines were secreted as a result of human immunodeficiency virus (HIV) and simian immunodeficiency virus (SIV) infections and were implicated in suppressing viral activity [8-9]. The effect of chemokines, MIP-1 $\alpha$ and RANTES, on CAEV replication has not been investigated. Therefore, the present study was conducted, 1) to evaluate the effect of CAEV infection on the expression of MIP-1 $\alpha$ by RT-PCR, and 2) to determine the effect of exogenous RANTES and MIP-1 $\alpha$ on the replication of CAEV in vitro.

\section{Materials and Methods}

\section{Inoculation of goats with caprine arthritis encephalitis virus}

A total of six adult female mixed-breed goats were infected approximately 3 years ago with CAEV

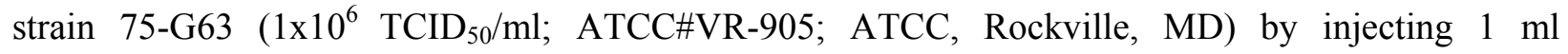
intravenously and intraarticularly [10]. Goats were confirmed seropositive to the major internal 
structural protein of CAEV by the agar gel immunodiffusion test (AGID; Veterinary diagnostic technology, Denver, CO) and by the polymerase chain reaction (PCR) technique [11]. CAEV-infected goats were showing varying degrees of arthritis at the time of this study. Six age and sex-matched, uninfected goats, confirmed seronegative by the agar gel immunodiffusion test and PCR technique were used as controls. Tuskegee University animal care and use committee approved the protocol for use and experimental infection of goats with CAEV.

\section{Isolation and preparation of peripheral blood mononuclear cells (PBMC)}

Blood samples from control and CAEV-infected goats were collected into $10 \mathrm{ml}$ vacutainers (Becton Dickinson, Franklin Lakes, NJ) containing sodium heparin by jugular venipuncture. PBM cells were isolated by density gradient centrifugation. Freshly collected blood was centrifuged at $275 \mathrm{x}$ $\mathrm{g}$ for $10 \mathrm{~min}$. Supernatant was discarded and the buffy coat diluted in $5 \mathrm{ml}$ of RPMI-1640 medium was carefully layered on approximately $4 \mathrm{ml}$ of Histopaque-1077 (Sigma, St. Louis, MO) and centrifuged at $800 \mathrm{x} \mathrm{g}$ for $20 \mathrm{~min}$. The PBM cells that resolved into a white, buffy coat at the interface were collected and transferred into fresh $15 \mathrm{ml}$ sterile centrifuge tubes. These cells were washed with $5 \mathrm{ml}$ PBS by centrifuging at $450 \mathrm{x}$ for $10 \mathrm{~min}$, counted and $10 \times 10^{6}$ cells/ ml were used for the isolation of RNA.

\section{Goat synovial membrane cell culture \& CAEV cultivation}

Goat synovial membrane cells, collected from 1 day-old goat kid, were grown under $5 \% \mathrm{CO}_{2}$ in minimal essential medium (MEM) containing 10\% fetal bovine serum (FBS) and 10\% streptomycin (Sigma, St. Louis, MO). The adherent cell layers were passaged at confluence. To infect, 1 X $10^{6}$ TCID $_{50} / \mathrm{ml}$ of CAEV strain 63 in MEM medium was added to GSM cells grown in $75 \mathrm{~cm}^{2}$ tissue culture flasks and incubated at $37^{\circ} \mathrm{C}$ for $24 \mathrm{~h}$. The control uninfected and infected GSM cells were then used for RNA isolation.

\section{RNA isolation \& cDNA synthesis}

Total RNA was isolated using an RNA isolation kit (Ambion Inc, Austin, TX). RNA was treated with DNase to eliminate any DNA contamination and confirmed by agarose gel electrophoresis. Approximately $2 \mu \mathrm{g}$ RNA was used to synthesize cDNA using the random primers included in the RETROscript $^{\mathrm{TM}}$ kit (Ambion, Austin, TX). cDNA was used immediately for polymerase chain reaction (PCR) or stored at $-20^{\circ} \mathrm{C}$ until needed.

\section{Construction of goat MIP-1 $\alpha$ cDNA clone}

Human MIP-1 $\alpha$ primers (BioSource International Inc, Camarillo, CA) were used initially to amplify a 279 bp product from total RNA isolated from CAEV-infected goats. The amplified product was cloned into pCR 2.1 vector, using original TA cloning kit (Invitrogen, Carlsden, CA) in order to 
sequence the PCR product using M13 forward and reverse primers. The PCR product was sequenced in the DNA Sequencing Laboratory (University of Arkansas for Medical Sciences, Little Rock, AR). Goat specific primers, goat forward MIP-1 $\alpha$ primer (GFMIP) and goat reverse MIP-1 $\alpha$ primer (GRMIP) were then designed from the sequence to amplify a 324 bp product of goat MIP-1 $\alpha$.

\section{RT-PCR for MIP-1 $\alpha$}

Amplification of goat MIP- $1 \alpha$ sequences from cDNA was performed using a Supertaq ${ }^{\mathrm{TM}}$ Plus kit (Ambion Inc, Austin, TX). The PCR reaction contained $1 \mathrm{X}$ reaction buffer (10 mM Tris-HCl, $\mathrm{pH} 8.3$, $50 \mathrm{mM} \mathrm{KCl}$ and $1.5 \mathrm{mM} \mathrm{MgCl}_{2}$ ), $2.5 \mathrm{mM}$ of each dNTP, $1 \mu \mathrm{g}$ of sense primer GFMIP (5' TCAGCAGATCTCTGCCATGAG3'), $1 \mu \mathrm{g}$ of antisense primer GRMIP (5'TGGTGTCGCTTAGGGACTTG3') and 1.5 units of Taq polymerase in a total volume of $50 \mu 1$. The PCR primers used were expected to amplify a 324 bp product of MIP-1 $\alpha$. After an initial denaturation at $94^{\circ} \mathrm{C}$ for $5 \mathrm{~min}$, the reaction mixture was subjected to 35 cycles of thermal cycling at $94^{\circ} \mathrm{C}$ for $1 \mathrm{~min}$ for denaturation, at $57.7^{\circ} \mathrm{C}$ for $1 \mathrm{~min}$ for annealing and at $72^{\circ} \mathrm{C}$ for $1 \mathrm{~min}$ for extension. Finally a $7 \mathrm{~min}$ extension at $72^{\circ} \mathrm{C}$ was performed after the last cycle (Perkin Elmer GeneAmp PCR System 2400). PCR products $(10 \mu 1)$ were electrophoresed in $2 \%$ agarose in TBE (Fisher Scientific, Pittsburgh, PA), visualized using ethidium bromide and photographed utilizing ultraviolet transillumination.

Attempts to amplify RANTES sequence in goat PBM cells and GSM cells using human RANTES primers have been unsuccessful.

\section{Densitometric analysis of RT-PCR products}

Polaroid pictures obtained of the RT-PCR electrophoresis gels were scanned into photoShop $6.0^{\mathrm{TM}}$. Areas were delineated using the 'free hand lasso' PhotoShop $6.0^{\mathrm{TM}}$, and were computed using histogram measurements.

\section{Effect of exogenous RANTES and MIP-1 $\alpha$ on the replication of CAEV in GSMC}

To determine the effect of exogenous RANTES and MIP- $1 \alpha$ on the replication of CAE virus in vitro, GSM cells were grown in 6-well tissue culture plates. Upon confluence, either $20 \mathrm{ng} / \mathrm{ml} \mathrm{rHu}$ (recombinant human) RANTES or $20 \mathrm{ng} / \mathrm{ml} \mathrm{rHu} \mathrm{MIP-1} \alpha$ was added to the monolayers of GSM cells and incubated at $37^{\circ} \mathrm{C}$ for $3 \mathrm{~h} .1 \times 10^{6} \mathrm{TCID}_{50} / \mathrm{ml}(100 \mu \mathrm{l})$ of CAEV strain 63 was then added to infect the GSM cells and incubated at $37^{\circ} \mathrm{C}$ for $72 \mathrm{~h}$ under $5 \% \mathrm{CO}_{2}$. In addition, RANTES and MIP-1 $\alpha$ were also added to the cells at $24 \mathrm{~h}$ and $48 \mathrm{~h}$ post-infection. CAEV-infected GSM cells were observed daily for any signs of cytopathic effects. At the end of $72 \mathrm{~h}$ post-infection, supernatants were collected and frozen at $-70^{\circ} \mathrm{C}$ until analyzed for reverse transcriptase activity. The GSM cells were then stained with $1 \%$ Giemsa's stain. The average number of syncytia (multinucleated giant cells with 3 or more nuclei) was counted from 20 fields of each well to determine viral replication. 


\section{Determination of reverse transcriptase (RT) activity}

CAEV replication was also assessed by measuring the viral RT activity present in the infected GSMC culture supernatants $72 \mathrm{~h}$ after infection. RT activity was assayed using a colorimetric reverse transcriptase enzyme immunoassay kit (Roche Molecular Biochemicals, Nutley, NJ).

\section{Statistical analysis}

The data for area profiles of RT-PCR bands, RT activity and syncytia formation were presented as mean \pm SE. Differences between means of control and infected groups were determined by student $t$ test and values of $\mathrm{P} \leq 0.05$ were considered significant.

\section{Results}

\section{RT-PCR and gel electrophoresis analysis of MIP-1 $\alpha$ expression in GSMC and PBMC}

MIP-1 $\alpha$ was constitutively expressed in both GSM cells and PBM cells. RT-PCR amplification of RNA isolated from GSM cells revealed a band of approximately $324 \mathrm{bp}$ in both uninfected, control and CAEV-infected cells (Fig. 1).

However, expression of MIP-1 $\alpha$ was found to be higher in CAEV-infected cells relative to control, uninfected cells. Similarly, comparison of PCR products revealed that the PBMC of CAEV-infected goats showed greater expression of MIP-1 $\alpha$ compared to that of non-infected animals (Fig. 2). Results of area profiles of the RT-PCR bands also confirmed the differences of MIP-1 $\alpha$ expression between CAEV-infected and non-infected goats (Fig. 3). Within GSM cells, areas of RT-PCR bands of MIP-1 $\alpha$ varied significantly from non-infected cells to $\mathrm{CAEV}$-infected cells $(\mathrm{P} \leq 0.0035)$. Significant differences were also observed between total area measurements of MIP-1 $\alpha$ bands within PBMC $(\mathrm{P} \leq 0.036)$.

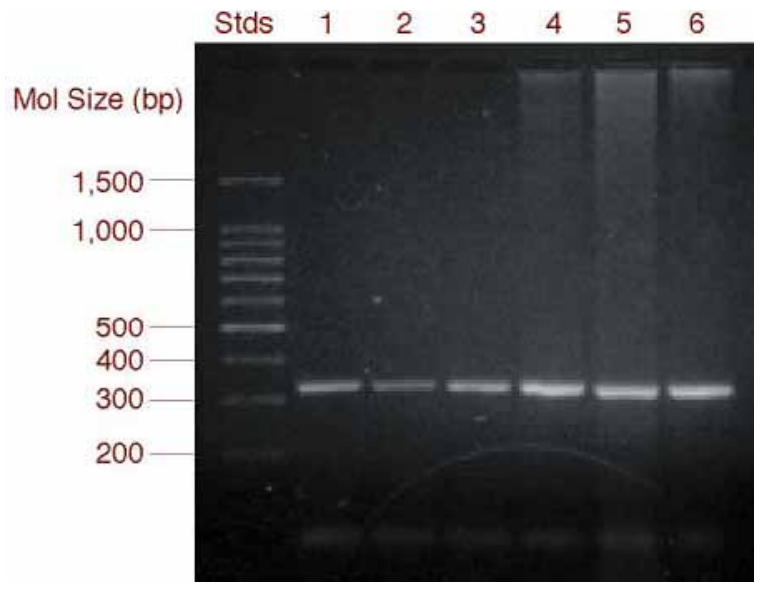

Figure 1. Effect of CAEV infection in vitro on the expression of a $324 \mathrm{bp}$ fragment of MIP-1 $\alpha$ mRNA in goat synovial membrane cells. Total RNA extracted from GSM cells was subjected to RT-PCR using goat specific primers. Samples were electrophoresed on a $\%$ agarose gel, stained with ethidium bromide and photographed utilizing ultraviolet transillumination. Stds: mol. size marker; Lanes 1-3: Control, uninfected GSM cells; Lanes 4-6: CAEV-infected GSM cells. 


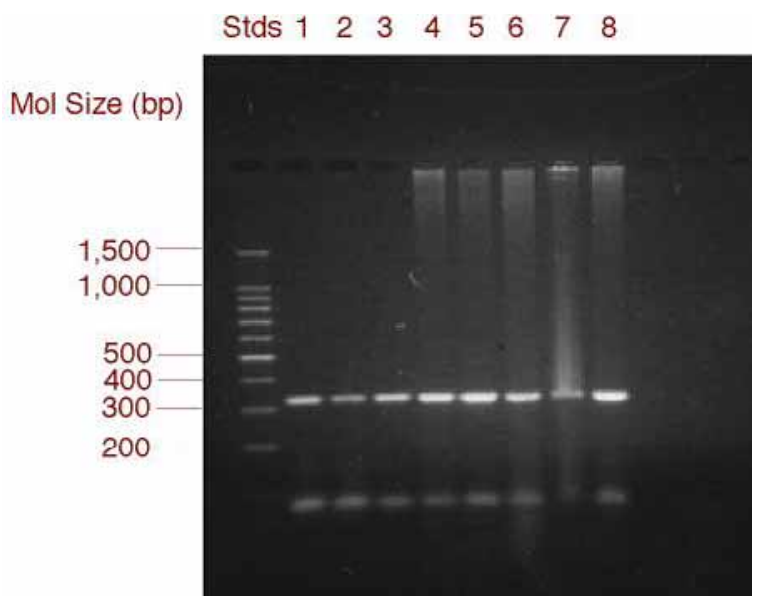

Figure 2. Effect of CAEV infection in vitro on the expression of a $324 \mathrm{bp}$ fragment of MIP-1 $\alpha$ mRNA in peripheral blood mononuclear cells of goats. Total RNA extracted from PBM cells was subjected to RT-PCR using goat specific primers. Samples were electrophoresed on a $\%$ agarose gel, stained with ethidium bromide and photographed utilizing ultraviolet transillumination. Stds: mol. size marker; Lanes 1-4: control PBMC isolated from uninfected goats; Lanes 5-8: PBMC isolated from CAEVinfected goats.

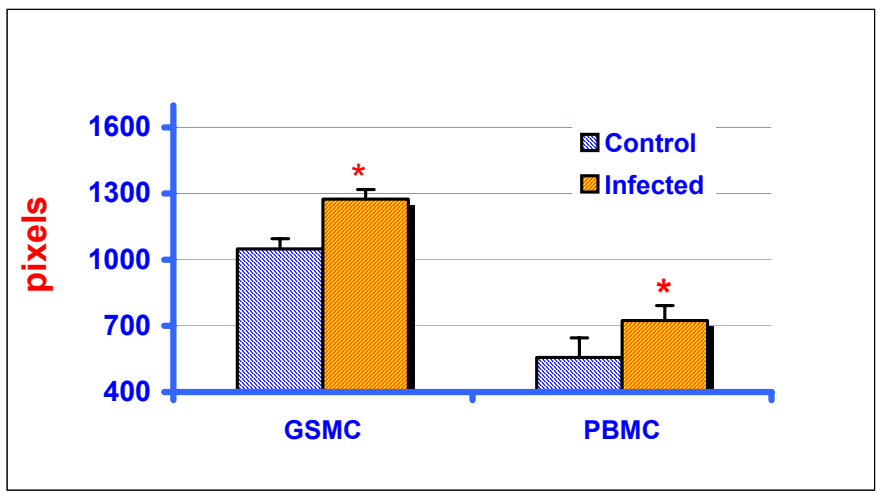

Figure 3. Area profiles of MIP-1 $\alpha$ RT-PCR bands of control, uninfected and CAEV-infected (in vitro) GSM cells, and PBM cells in non-infected and CAEV-infected goats. Areas were delineated using the 'free hand lasso' PhotoShop $6.0^{\mathrm{TM}}$, and were computed using histogram measurements. Significant differences were observed between control and CAEV-infected RT-PCR bands of both GSM cells $(\mathrm{P} \leq 0.0035)$ and $\mathrm{PBM}$ cells $(\mathrm{P} \leq 0.036)$. Area measurements were expressed as pixels. *indicates significant difference from control.

\section{Effect of exogenous chemokines on CAEV replication in vitro}

Exogenous chemokines had significant effect on the RT activity of caprine lentivirus $(\mathrm{P} \leq 0.05)$. Supernatants collected from the infected GSM cells at $72 \mathrm{~h}$ were assayed for RT activity using a sandwich ELISA method. Exogenous MIP-1 $\alpha(20 \mathrm{ng} / \mathrm{ml})$ reduced RT activity in GSM cells from 5.4 $\mathrm{pg} / \mathrm{ml}$ to $0.7 \mathrm{pg} / \mathrm{ml}(\mathrm{P} \leq 0.01)$, approximately an 8 fold reduction (Fig. 4). $20 \mathrm{ng} / \mathrm{ml}$ exogenous RANTES also reduced RT activity in GSM cells by 2 fold (P $\leq 0.01$ ), from $5.4 \mathrm{pg} / \mathrm{ml}$ to $2.65 \mathrm{pg} / \mathrm{ml}$ (Fig. 5). 


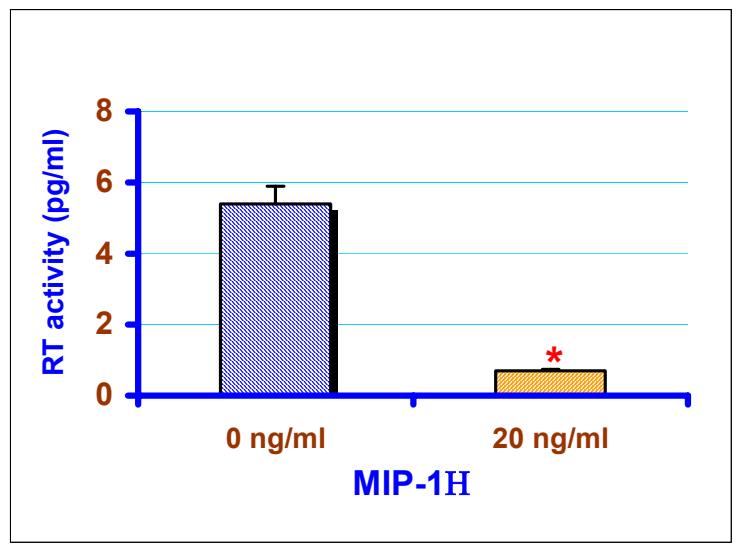

Figure 4. Exogenous $\mathrm{rHu}$ MIP-1 $\alpha$ decreases RT activity of CAEV in vitro. CAEV replication was assessed by measuring RT activity present in the GSM cell culture supernatants. Supernatants were collected $72 \mathrm{~h}$ post-infection for RT analysis. Mean RT value of MIP-1 $\alpha$ treated cell culture supernatant was $0.7 \mathrm{ng} / \mathrm{ml}$ compared to that of $5.4 \mathrm{ng} / \mathrm{ml}$ of control (no chemokine added) sample. *indicates significant difference from control $(\mathrm{P} \leq 0.01)$.

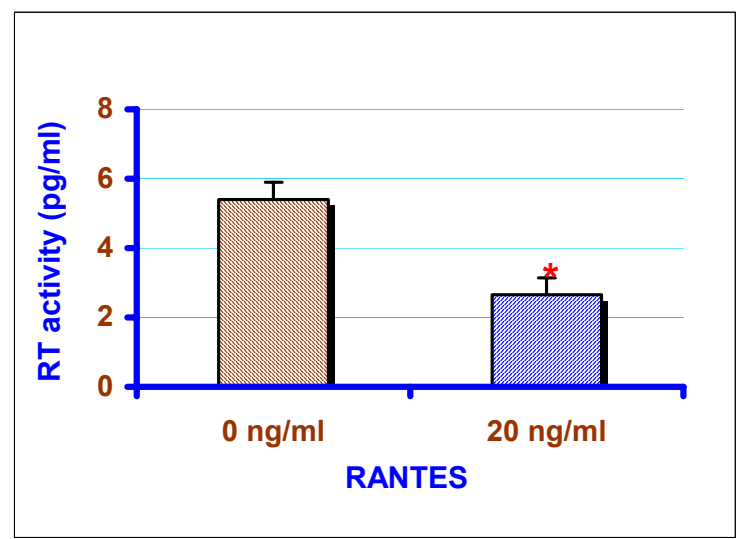

Figure 5. Exogenous rHu RANTES decreases RT activity of CAEV in vitro. CAEV replication was assessed by measuring RT activity present in the GSM cell- culture supernatants. Supernatants were collected $72 \mathrm{~h}$ post-infection for RT analysis. Mean RT value of RANTES was $2.65 \mathrm{ng} / \mathrm{ml}$ compared to $5.4 \mathrm{ng} / \mathrm{ml}$ of control (no chemokine added) sample. *indicates significant difference from control $(\mathrm{P} \leq 0.01)$.

Incubation of GSM cells with chemokines significantly reduced syncytia formation. Exogenous MIP-1 $\alpha(20 \mathrm{ng} / \mathrm{ml})$, and RANTES $(20 \mathrm{ng} / \mathrm{ml})$ reduced the number of syncytia by $75 \%$ and $65 \%$ respectively $(\mathrm{P} \leq 0.01)$ compared to the cells not treated with the chemokines (Fig. 6 and 7). 


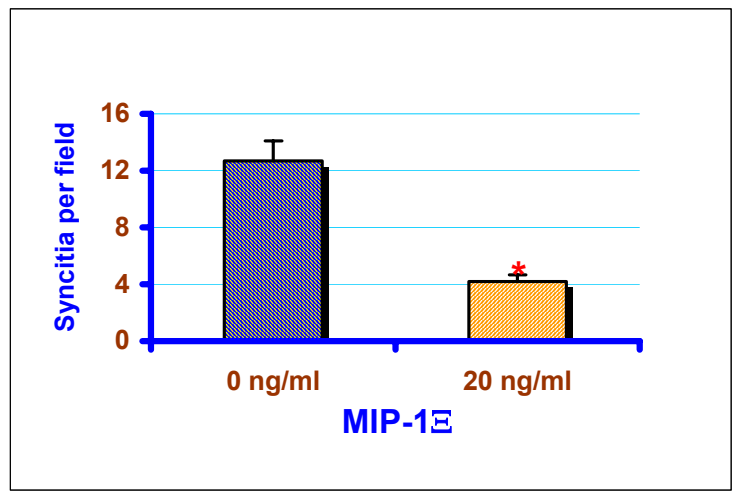

Figure 6. Exogenous MIP-1 $\alpha$ inhibits CAEV replication in GSMC in vitro. $\mathrm{rHu} 20 \mathrm{ng} / \mathrm{ml} \mathrm{MIP}-1 \alpha$ was added $3 \mathrm{~h}$ prior to infection with $1 \times 10^{6} \mathrm{TCID}_{50} / \mathrm{ml} \mathrm{CAEV}$, and at $24 \mathrm{~h}$ and $48 \mathrm{~h}$ post-infection. $\mathrm{rHu}$ MIP-1 $\alpha(20 \mathrm{ng} / \mathrm{ml})$ reduced syncytia formation by $75 \%$. After $72 \mathrm{~h}$, supernatants were harvested for the determination of RT activity. *indicates significant difference from control $(\mathrm{P} \leq 0.01)$.

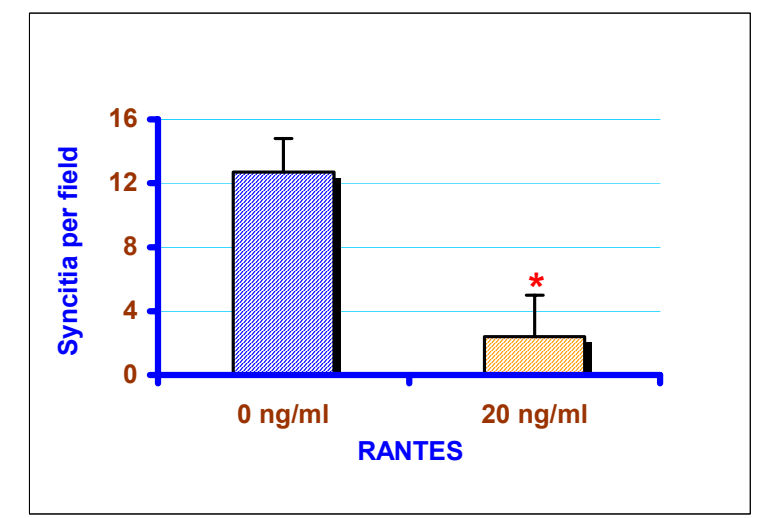

Figure 7. Exogenous RANTES inhibits CAEV replication in GSMC in vitro. $20 \mathrm{ng} / \mathrm{ml}$ exogenous RANTES was added $3 \mathrm{~h}$ prior to infection with 1 X $10^{6} \mathrm{TCID}_{50} / \mathrm{ml} \mathrm{CAEV}$, and at $24 \mathrm{~h}$ and $48 \mathrm{~h}$ postinfection. rHu RANTES reduced syncytia formation by $65 \%$. After $72 \mathrm{~h}$, supernatants were harvested for the determination of RT activity. *indicates significant difference from control $(\mathrm{P} \leq 0.01)$.

\section{Discussion}

The most significant biological functions of chemokines, leukocyte recruitment [12] and activation [4] are essential for a prompt and effective inflammatory response and in host defence against infections. RANTES and MIP-1 $\alpha$, which belong to the CC-chemokine family are critical in the establishment of chronic inflammation in various pathological conditions including rheumatoid arthritis [13-14]. MIP-1 $\alpha$ secreted locally by synovial fibroblasts and tissue macrophages was shown to recruit monocytes to the joint in RA [15] indicating the significant role played by this chemokine in the inflammatory process. Although the pathogenesis of chronic arthritis in CAEV-infected goats is not completely understood, changes in cytokine expression may be one of the factors involved [16, 7]. In the present study, RT-PCR analysis showed that MIP-1 $\alpha$ was constitutively expressed by goat 
synovial cells. However, CAEV infected GSM cells (in vitro) showed higher expression of MIP-1 $\alpha$ compared to non-infected GSM cells. Importantly, increased expression of MIP-1 $\alpha$ was also observed in PBM cells of CAEV-infected goats relative to that of non-infected goats. These results indicate that the CAEV infection may increase expression of MIP-1 $\alpha$, which may play an important role in the immounopathology observed in CAEV infection. It could be speculated that the increased activity of MIP-1 $\alpha$ in caprine lentiviral infection may stimulate the synthesis of other proinflammatory cytokines such as IL-1, IL-6 and TNF in both fibroblasts and macrophages. It may also induce or increase proliferation and activation of CC-chemokine activated killer cells (CHAK) thereby increasing host's ability to fight infection.

Recently, both RANTES and MIP-1 $\alpha$ were shown to have the ability to effectively inhibit lentiviral replication [8-9]. Activated CD8+ cells in HIV-infected humans and SIV-infected non-human primates secrete soluble factors such as RANTES, MIP- $1 \alpha$ and MIP- $1 \beta$ which act as antiviral factors. These antiviral factors were reported to decrease viral activity by decreasing its entry by competing with HIV-1 in binding to CCR5, the principal coreceptor for this virus $[16,17,8]$. However, it is not known if these chemokines exert any pertinent effect on CAEV replication. It has been reported that some cytokines such as lentivirus-induced interferon (LV-IFN) were capable of adversely affecting CAEV replication in vitro [19]. LV-IFN inhibits CAEV replication by suppressing monocyte proliferation and their maturation into macrophages and also by directly inhibiting CAEV gene expression in mature macrophages. Our results showed that exogenous RANTES and MIP- $1 \alpha$ significantly inhibit CAEV replication in GSM cells in vitro. Analysis of RT activity and the syncytia formation clearly indicated significant reductions of CAEV replication in the presence of exogenous RANTES or MIP-1 $\alpha$. Like other chemokines, RANTES and MIP-1 $\alpha$ mediate their effects on cells via G protein coupled receptors that contain seven transmembrane spanning regions [20]. CCR1 and CCR5 act as receptors for both RANTES and MIP-1 $\alpha$ [21-22], and can bind these chemokines with similar affinities. Incubation of GSM cells with both RANTES and MIP- $1 \alpha$ did not result in any further decreases in CAEV activity (data not shown). This absence of combined effects of RANTES and MIP- $1 \alpha$ could be attributed to the fact that RANTES and MIP-1 $\alpha$ share same binding sites on CCR1 and CCR5 receptors. The exact mechanism by which these chemokines inhibit CAEV activity and replication is currently under investigation.

Based on the results of this study, it could be speculated that increased production of chemokines due to lentiviral infection play a dual role in the infected goat. They may help in reducing viral replication by directly affecting viral attachment to the macrophages or by inhibiting viral transcription [23]. However, they may also contribute to the development of arthritis because of their chemotactic ability to attract $\mathrm{T}$ cells and macrophages, as well as activation of these cells leading to the production of other proinflammatory cytokines. Further investigations are needed to understand the precise role of 
these chemokines in the regulation of CAEV replication and in the immunopathology in the infected goat.

\section{Acknowledgements}

This work has been supported by NIH/NCRR/RCMI grant no. 5 G12RR03059. The authors are thankful to Dr. John W. Williams, Dr. Prem Kumar and RCMI (Research Centers for Minority Institutions) staff and at the Center for Biomedical Research for providing technical assistance.

\section{References and Notes}

1. Narayan, O.; Clements, J.E. Biology and pathogenesis of lentiviruses. J. Gen. Virol. 1989, 70, 1617-1639.

2. Feldmann, M.; Brennan, F.M.; Maini, R.N. Role of cytokines in rheumatiod arthritis. Annu. Rev. Immunol. 1996, 14, 397-440.

3. Schall, T.J.; and Bacon, K.B. Chemokines, leucocyte trafficking, and inflammation. Curr. Opin. Immunol. 1994, 6, 865-873.

4. Baggiolini, M..; Dewald, D.; Moser, B. Interleukin-8 and related chemotactic cytokines: CXC and CC chemokines. Adv. Immonol. 1994, 55, 97-179.

5. Bischoff, S.; Krieger, M..; Brunner, T.; Rot, A.; von Tscharner, V.; baggioini, M.; Dahinden, C. RANTES and related chemokines activate human basophil granulocytes through different $\mathrm{G}$ protein-coupled receptors. Eur. J. Immunol. 1993, 23, 761-767.

6. Rathanaswami, P.; Hachicha, M.; Sadick, M..; Schall, T.J.; McColl, S.R. Expression of the cytokine RANTES in human rheumatiod synovial fibroblasts. Differential regulation of RANTES and interleukin-8 genes by inflammatory cytokines. J. Biol. Chem. 1993, 268, 5834-5839.

7. Lechner F.; Machado, J.; Bertoni, G.; Seow, H.F.; Dobbalaere, D.A.E.; Peterhans, E. Caprine arthritis encephalitis virus dysregulates the expression of cytokines in macrophages. J. Virol. 1997, 71, 7488-7497.

8. Cocchi, F.; Devico, A.L.; Garzino-Demo, A.; Arya, S.K.; Gallo, R.C.; Lusso, P. Identification of RANTES, MIP-1alpha, MIP-1beta as the major HIV-suppressive factors produced by $\mathrm{CD} 8^{+} \mathrm{T}$ cells. Science 1995, 270, 1811-1815.

9. Coffey, M.J.; Woffendin, C.; Phare, S.M.; Strieter, R.M.; Markovitz, D.M.. RANTES inhibits HIV-1 replication in human peripheral blood monocytes and alveolar macrophages. Am. J. Physiol. 1997, 272, L1025-L1029.

10. Crawford, T.B.; Adams, D.S.; Cheevers, W.P.; Cork, L.C. Chronic arthritis in goats caused by retrovirus. Science 1980, 207, 997-999.

11. Reddy, P.G.; Sapp, W.J.; Heneine, W. Detection of caprine arthritis encephalitis virus by polymerase chain reaction. J. Clin. Microbiol. 1993, 31, 3042-3043.

12. Adams, D.H.; Shaw, S. Luecocyte-endothlial interactions and regulation of leucocyte migration. The Lancet 1994, 343, 831-836. 
13. Furie, M.B.; Randolph, G.J. Chemokines and tissue injury. Am. J. Pathol. 1995, 146, 1287-1301.

14. Pulsatelli, L.; Meliconi, R.; Boiardi, L.; Macchioni, P.; Salvarani, C.; Faccini, A. Elevated serum concentrations of chemokine RANTES in patients with polymyalgia rheumatica. Clin. Exp. Rheumatol. 1998, 16, 263-268.

15. Kunkel, S.L.; Lukacs, N.; Kasama, T.; Strieter, R.M. The role of chemokines in inflmmatory joint disease. J. Leukoc. Biol. 1996, 59, 6-12.

16. Peterhans, E.; Pohl, B.; Zanoni, R.; Lazary, S. Caprine arthritis encephalitis, In Rheumatoid arthritis, Smolen, J.S., Kalden, J.R., Maini, R.N., Ed.; Springer, Heidelberg, Germany, 1992; pp 216-230.

17. Walker, C.M.; Levy, J.A. A diffusible lymphokine produced by CD8+ T lymphocytes suppresses HIV replication. Immunol. 1989, 66, 628-630.

18. Baier, M.; Werner, A.; Bannert, N.; Metzner, K.; Kurth, R. HIV suppression by interleukin-16. Nature 1995, 378, 561.

19. Zink, M.C.; Narayan, O. Lentivirus-induced interferon inhibits maturation and proliferation of monocytes and restricts the replication of caprine arthritis-encephalitis virus. J. Virol. 1989, 63, 2578-2584.

20. Bembaruch, A.; Michiel, D.F.; Oppenheim, J.J. Signals and receptors involved in recruitment of inflammatory cells. J. Biol. Chem. 1995, 270, 11703-11706.

21. Neote, K.; DiGregorio, D.; Mark, J.Y.; Horuk, R.; Schall, T.J. Molecular cloning, functional expression, and signaling characteristics of a C-C chemokine receptor. Cell 1993, 72, 415-425.

22. Deng, H.; Liu, R.; Ellmeier, W.; Choe, S.; Untmaz, D.; Burkhart, M.; DiMarzio, P.; Marmon, S.; Sutton, R.E.; Hill, C.M.; Davis, C.B.; Peiper, S.C.; Schall, T.J.; Littman, D.R.; Landau, N.R. Identification of a major co-receptor for primary isolates of HIV-1. Nature 1996, 381, 661-666.

23. Mackewicz, C.E.; Blackbourn, D.J.; Levy, J.A. CD8 ${ }^{+}$T cells suppress human immunodeficiency virus replication by inhibiting viral transcription. J. Immunol. 1995, 163, 3653-3661.

(C) 2002 by MDPI (http://www.mdpi.org). 